\title{
抗てんかん萝血中寒度測定に基づく投薬管理
}

\author{
細田宣代, ${ }^{* 1}$ 安田暢子, 千田富子, 小畑佑子*2 \\ 立川相互病院薬凨部*1 \\ 多摩保険調鼡薬局*2
}

\section{Regulation of Anticonvulsant Therapeutic Schedule by Serum Concentrations}

\author{
NORIYO HOSODA, ${ }^{* 1}$ NOBUKO YASUDA, \\ TOMIKO SENDA and YUKO OBATA*2
}

Pharmacy, Tachikawa Sogo Hospital, *1 Tama Pharmacy*2

(Received November 28, 1983)

In an attempt to improve the anticonvulsant therapy, the serum concentration of phenobarbital (PB), valproic acid (VPA) and phenytoin (PHT) was assessed in 62 pediatric patients who were treated with these drugs administered alone or concomitantly. The serum concentration of PB was higher when administered concomitantly with PHT or VPA as compared with that when administered alone. Conversely, the serum concentration of VPA tended to be lowered when administered in conjunction with PB. Good correlations were demonstrated between the determined concentration of PB or VPA and those predicted by the pharmacokinetic calculation.

A case report was described referring to the therapeutic schedule of PB and PHT, their serum concentrations, occurrence of adverse effects and the symptoms. It was indicated that determination of serum concentration of administered anticonvulsants may prevent the possible adverse effects and be useful for improving the therapeutic schedule.

Keywords - phenobarbital; phenytoin; valproic acid; serum concentration; drug interaction; pharmacokinetics; epilepsy; adverse effects

抗てんかん薬血中濃度測定の臨床的意義はさまざまで あるが,1) 著者らはそれらの意義に加えて, 薬剤師の臨 床への参加の一つの場としても位置づけ，1980年10月に 我々自身で試験的に測定を実施した. 1981年 6 月に特定 薬凧治療管理料として保険適用が認められ，12月から当 院臨床検查室での測定が開始された. その後 8 力月間の 測定結果についてフェノベルビタール濃度に及ぼすフェ ニトイン併用の影響及びフェノバルビタールとバルプロ 酸との薬物間相互作用, 推定理論值一測定値間の 相 関 性, 副作用を調查したので報告する.また薬物間相互作 用が関与していると思われる症例を報告する。

*1 立川市錦町 1 丁 目 16-15；16-15, Nishiki-cho 1-chome, Tachikawa, 190 Japan

*2 立川市錦町 1 丁目 16-14；16-14, Nishiki-cho 1-chome, Tachikawa, 190 Japan

\section{拥 查 方 法}

\section{1. 方 法}

1982年 7 月現在，小児科外来で抗てんかん薬の投与を らけている62名の患者 $(2 \sim 6$ 歳19人, $7 \sim 12$ 歳 33 人, 13〜17歳10人）について，1981年12月から1982年 7月 での期間に測定された血清中濃度測定結果について調査 した. 62例中51例が何らかの型のてんかんと診断されて おり，他泳合型熱性けいれんであった。治療は45 例 (73\%) が単剤投与であり,フェノバルビタール（以下 PB) 25例, バルプロ酸 (以下 VPA) 16例, フェ $=ト 1$ ン(以下 $\mathrm{PHT}$ ), カルバマゼピン (以下 $\mathrm{CBZ}$ ) 各 2 例 であった。 2 剂投与が10例， 3 剂投与が 6 例， 4 斉投与 が 1 例であり，単昘投与が汪とんどであった。測定デー 夕は， 1 人の患者汇関して 2 件以上の場合もあるので, 


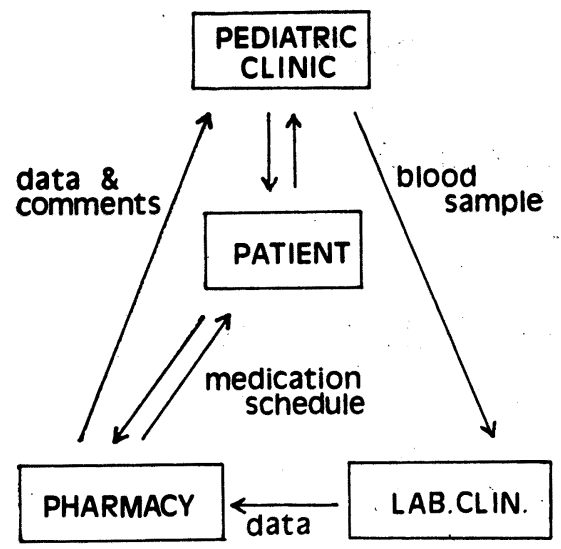

図 1. System of Therapeutic Drug Level Monitoring

症例数と測定件数とは一致しない.

\section{2. 血洋中湌度モニタリング・システム}

血清中濃度モニタリングは図1のシステムによって行 われている. 緊急を要しない場合には，測定 2 週間前に 菓局で血清中濃度測定の意義と服薬について患者指導を する．採血日も服薬して来院してもらう．採血時間は， できるたけ服薬 $2 \sim 4$ 時間後，または次回服薬直前とな るようにした。測定は臨床検查室で行われ，測定結果が 菓局に送られる：薬局では推定理論值を計算するなどし て，必要に応じてコメントをつけて結果を小児科に報告 する.

抗てんかん薬の血清中濃度測定は Syva Semi-automatic :System （第一化学薬品株式会社）を用いて, EMIT 法によって行った.

\section{結果}

PB の血清中濃度に及ぼす PHT 併用の影響を図 2 に 示した. PB 単独投与群に比へ, PHT 併用群では血清中 PB 濃度が高値を示す傾向を示した．しかし，PB 単独 投与群では大きなバラッキが見られ，また投与量によっ ては併用群の方が低い例もあり，個々の患者についての 詳細な検討を加える必要性があると思われた，血清中 PB 濃度は大部分治療有効域内にあったが, 有効域以下 の例は怠薬, 散剤の领み残し（分包の中に残る，ジュ一 スに混ぜたとき，コップの壁につく）などの理由による めのであり，高値を示した 2 例は軽度の腎機能障害があ ったので，これが原因かるしれないと思われた。

PB の血清中濃度に及ぼす VPA の影響を図3飞示 す. PB 単独群飞比し、VPA 併用群では PB 血清中濃 度が高くなる傾向がみられた。 反対に PB 併用によって

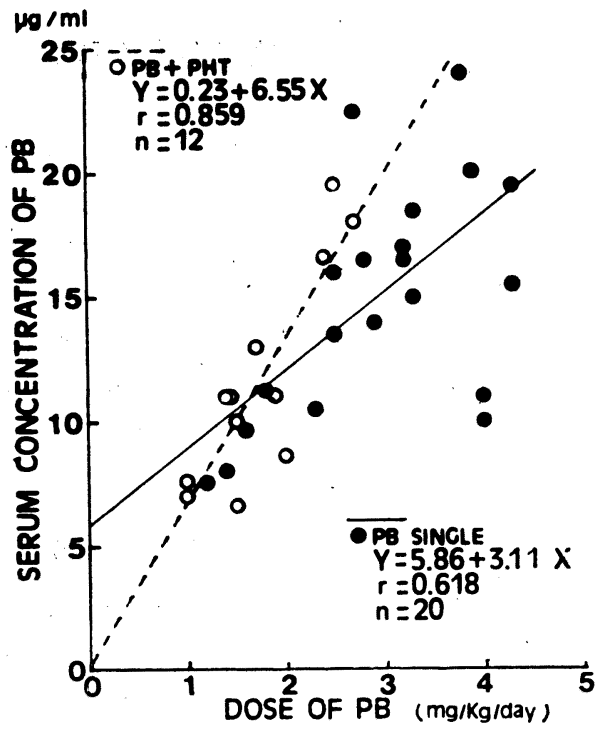

図 2. Effect of PHT on Serum PB Level

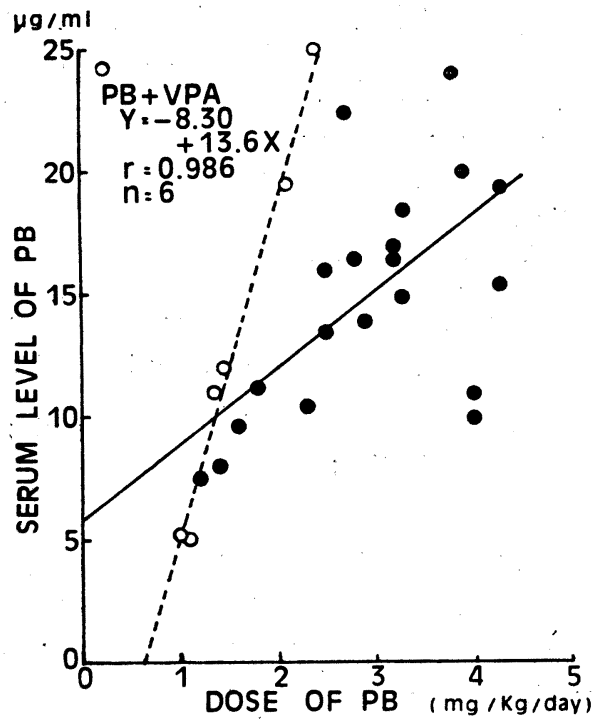

図 3. Effect of VPA on Serum PB Level

VPA の血清中濃度は VPA 単独投与群より低值を示す 傾向がみられたが(因 4)，いずれる相関俰数における有 意性がなく，有意な差であるとはいえなかったＶVPA の血清中濃度が治療有效域以下となったものが数例あっ たが，これらのほとんどで急薬がみられておりこれに よるものかもしれない，また，投与量が少ないことも考 えられる，1例は減量中であった．非常に高値を示した ものが1例あったが，この例ではとくに副作用の発現も なく，高値の原因す不明であった。 


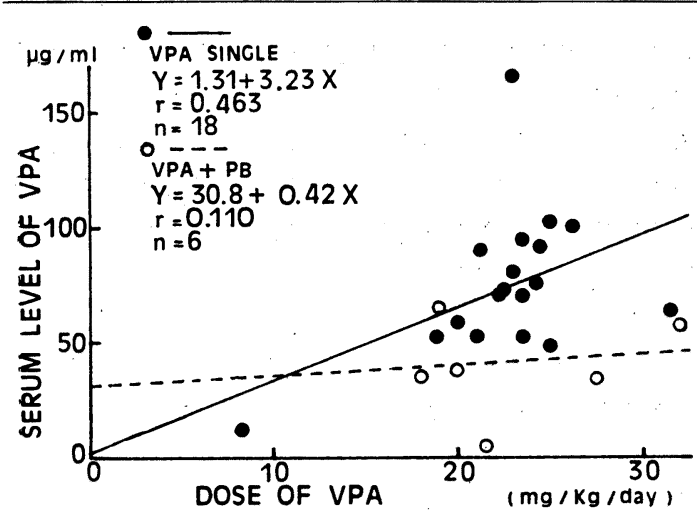

図 4. Effect of PB on Serum VPA Level

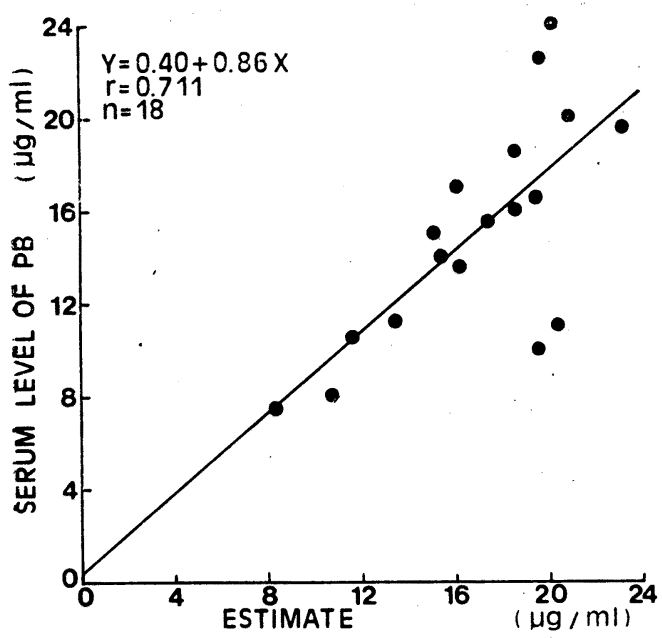

図 5. Regression of Serum PB Level on Theoretical Estimate Based on Dosage

薬物動力学に基づき推定した PB および VPA 単剤投 与例に拈ける理論的血清中濃度と測定值との相関を示し たのが図 5 および図 6 である.いずれる高い相関性を示 した.

図 7 の症例は，14歳男児（体重 $40 \mathrm{~kg}$ ）で, てんかん （強直間代けいれん）と診断された. 1982年 4 月まで $\mathrm{PB}$-PHT 合剂 (ヒダントール F ; 1 錠中 $\mathrm{PB} 67 \mathrm{mg}$, PHT $200 \mathrm{mg}$ ，藤永）が投与されていた，そのときの血 清中濃度は PB 13.0, PHT $15.0 \mu \mathrm{g} / \mathrm{ml}$ (服用後 7 時間) であった. その後 PB（フェノバルビタール錠，藤永） そ PHT (アレビフチン錠, 大日本) の単味剤でそれぞ れ $60 \mathrm{mg} /$ 日， $200 \mathrm{mg} /$ 日が投与された. 7 月29日眠気を 訴えたため血清中濃度を測定したところ，服用後10時間 で PB $6.6 \mu \mathrm{g} / \mathrm{ml}$, PHT $8.0 \mu \mathrm{g} / \mathrm{ml}$ であった.ここで, 臨床経過が良好であるため，PHT 単阂投与としていく

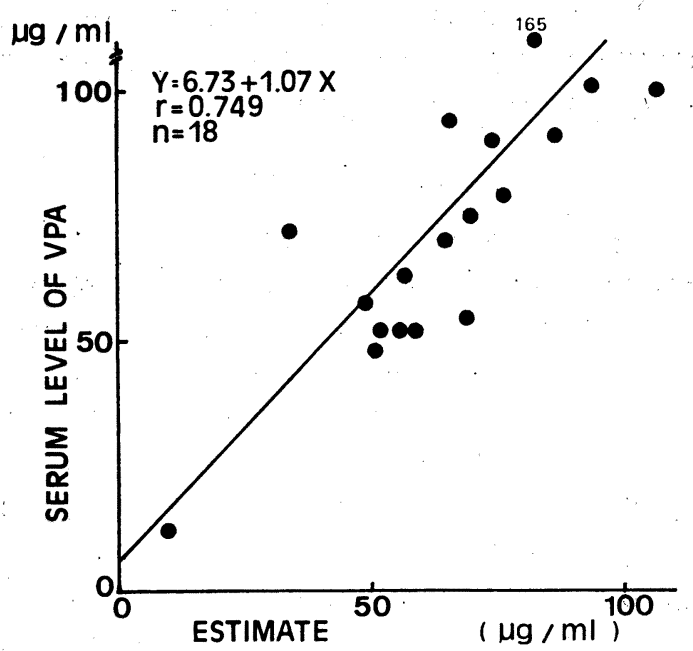

図 6. Regression of Serum VPA Level on Theoretical Estimate Based on Dosage

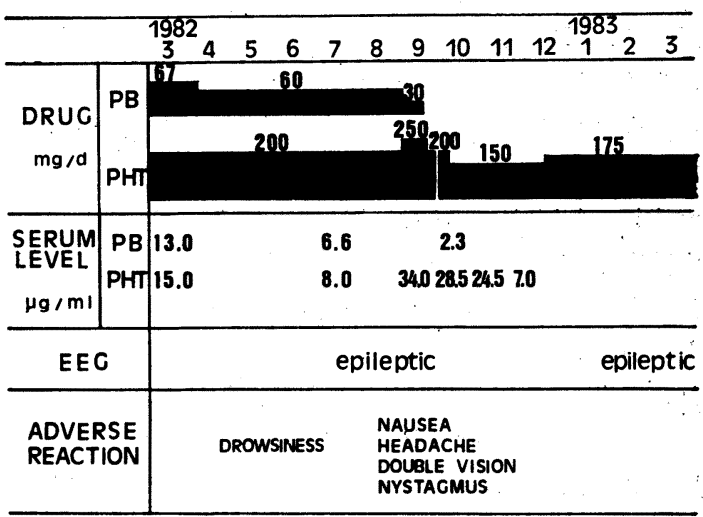

図 7. Case. I.S. 14 Years Old, Boy, Epilepsy

目的で，9月 2 日 $\mathrm{PB}$ が $30 \mathrm{mg} /$ 日に減らされ, PHT が $250 \mathrm{mg} /$ 日（アレビアチン錠 $200 \mathrm{mg}+$ ヒダントール 錠 $50 \mathrm{mg}$, 藤永) に増量された. 9 月10日から嘔気, 頭痛, 食欲不振が出現し持続したため，9月16日に PHTを一 時中止するよう指示されたが，患者は反対に PBを中止 し，PHT $250 \mathrm{mg} /$ 日を服用し続けた. 9 月16日の血清中 PHT 濃度は $34.0 \mu \mathrm{g} / \mathrm{ml}$ であり，9月20日から前記症 状に複視, 水平眼振が加わったため PHTは $200 \mathrm{mg} /$ 日 に減量された。しかしな特時々複視, 眼振が軽度に継続 した. 9 月27日の血清中濃度は $28.5 \mu \mathrm{g} / \mathrm{ml}$ とまだ高値 を示したため，服薬を 1 日休止とされた。以後再び 200 $\mathrm{mg} /$ 日が投与されたが，な捜複視が続き，血清中濃度も $24.5 \mu \mathrm{g} / \mathrm{ml}$ (最終服薬22時間後) と高いため，10月 7 日 から $150 \mathrm{mg} /$ 日に減量となった。 その後は上記の自覚 
(副作用)症状はみられず, 血清中濃度も $7.0 \mu \mathrm{g} / \mathrm{ml}(12$ 時間後）と治療範囲よりやや低值であった。 以後は 175 $\mathrm{mg} /$ 日で発作はコントロールされた.

\section{考寮}

薬物の血中濃度モニタリングは薬物療法に欠くことの できないこととなりつつある.著者らは臨床薬剤師の活 動の一環として血中濃度測定を位置つけ，図 1 のシステ ムによって, 薬剤部では測定結果の解析等を行ってい る. 単剤投与の場合には血清中濃度の予測が比較的容易 であるが，2剂以上の多剂投与となると薬物間相互作用 を考虑しなくてはならない，多数の報告で，PHTはPB の血中濃度を上昇させると述べられて㧍り，PHTによ る PB 代謝の競合的阻害または尿中排泄の低下などが考 えられる.2) 西原ら (1978) は, PHT の併用により PB の代謝物 p-HPB およびその抱合体の尿中排泄が減少す ることを報告している. ${ }^{3)}$ 反対に, PB 併用によって PHT 血中濃度は低下する，上昇する，变化しないなどの報告 がある.PBは肝ミクロゾーム酵素系の誘導により PHT の生体内代謝を增強させ, さらに PHT の内服時の吸収 を減少させ, 4) PHT の血中濃度を低下させるものと考兄 られる. 一方では PB は PHT 代謝酵素作用の competitive inhibitor であり,2) これによって PHT の血 中濃度は上昇する。したがって PB と PHT を併用乙 た場合の作用については，増強する，あるいは減弱する とはいちがいにはいえない，通常は PB の作用が增強さ れ，PHT の作用が減弱されると考兄られる.

著者らの結果では, PB 単独投与群に比し, PB-PHT 併 用群において PB 血清中濃度が高かった. PHT 単独投 与例が少数であったため, PHT 血清中濃度に対する PB 併用の影響については述べなかったが，併用例に和ける PHT 血清中濃度は全般低く，上述の上うな相互作用 によるるのと思われた。

症例(因 7 )飞执いては，PB-PHT 併用によってPHT の血清中濃度が抑えられていたところ，PB の服用を中 止したために PB の影響がなくなったことと, PHT の投 与量を $200 \mathrm{mg} /$ 日から $250 \mathrm{mg}$ /日に增加したことのため 飞血清中濃度が大きく上昇したことが考えられる．PBPHT 併用例淿心て，PB を中止する際にはきわめて 注意深く行う必要のあることが示唆された。

VPA の併用により PB の消失半隇期は約 1.4 倍に延 長するが，腎クリアランスは変わらない，尿中に排泄さ
れる $\mathrm{p}-\mathrm{HPB}$ と PB の量比が単独服用患者に比べて小 さくなる、らなどの点から VPA は PB の代謝を抑制す るものと考学られている. 反対に PB は肝の VPA 代謝 酵素を誘導する ${ }^{6)}$ と考えられ，PB 併用によって VPA 血中濃度は低下するとされている．岡田らの報告》) と同 様に，著者らの調査結果に扰いてもこれらの相互作用が 示された.

今回の調査に捛いては，副作用としては次のようなも のがみられたＰBによる眠気，PHT による多毛，歯 肉堌殖, 眠気, VPA による腹痛, 食欲不振, 湢気, 嘔 吐, 口角炎, 眠気, CBZ による眠気. いずれる軽度で あったが，図 7 の症例のように，PHT による強い眠気 や複視，水平眼振を発現した例もあるため，血清中濃度 測定, 理論的血清中濃度推定, 問猃などがきわめて重要 であると感じられた。 また，血中濃度測定以前の問題と して, 服薬指導, コンプライアンスの問題が非常に重要 であることが示唆された。この症例の場合, 血清中濃度 測定がもっと迅速に行われれば, 重篤な副作用の発現を 防ぐことができたかもしれないことも痛感した。

また，特に小児の場合には，薬物速度論に基づく血中 濃度の推定や投与設計》が重要となるが, 頻回に採血し 血清中濃度を測定することが困難である.

今後は, 患者毎の動態值や小児に見合った薬物動態値 の検索などにより，測定データの解析をさらに適切に行 い, 薬物治療計画に積極的に参加していきたいと考え る.

竍辞本稿をまとめるにあたり，立川相互病院小児科 柳恵子医師に，で指導，で協力をいただいたととを深謝 する.

\section{引用 文 菐}

1）三浦寿男ほか：脳と発達，12，130 (1980).

2) 大田卓生ほか：脳と発達, 11,515 (1979).

3）西原カズョ: “薬物血中濃度测定の実際, ”薬業時 報社, 1981, p. 154 168.

4) L.S.Goodman, A.Gilman: “クッドマン・ギル マン薬理書," 第 5 版, 廣川書店, 1981, p. 248〜 279.

5) I. H. Patel, et al. : Clin. Pharmacol. Ther.,27, 515 (1980).

6）松岡収ほか：睬と発達，11，577 (1979).

7) 岡田弘康ほか：JJSHP，19，625 (1983).

8）石崎高志ほか：臨床精神医学，7，283 (1978)。 